\title{
Digital Didactic Materials: An Innovative Resource for Teaching in the 21st Century
}

\author{
Carolina Real Torres \\ Universidad de La Laguna - Tenerife
}

The unstoppable technological progress that shakes our society has reached the academic classrooms and, with it, the development of new teaching methods. The advance of ICTs has modified the way of elaborating, acquiring and transmitting knowledge, promoting the use of innovative tools for learning. Within the wide range of new educational possibilities offered by these tools, open access didactic materials in digital format acquire vital importance as a source of information and as the axis for the development of new pedagogical methods.

In this sense, the purpose of this paper is to present a model of integration of DDM (Digital Didactic Materials), highlighting the possible didactic uses offered by these resources, and to promote their design as a dynamic strategy for autonomous work, motivation and improvement of students' academic performance.

Keywords: digital didactic materials, ICT (Information and Communication Technologies), OER (Open Educational Resources), authoring tools, educational innovation

\section{INTRODUCTION}

The creation of educational materials is a key aspect of the incidence of ICTs and the digital world in general in the current educational panorama (Rodríguez, 2005). Their preparation for the teaching-learning process constitutes the central axis of any pedagogical strategy due to the numerous didactic possibilities they offer to work not only on conceptual content, but also on procedural and attitudinal content, contributing to the acquisition of competences.

Digital resources have emerged in recent decades as a means of expression and creation through a new language based on image, sound and interactivity, three elements that reinforce the understanding, creativity and motivation of students (García-Valcárcel, 2016). Audiovisual media involve a form of multisensory communication generating a multiplicity of codes that affect various senses and forms of perception, forming a language of synthesis adopted by young people as a new means of communication. The students who nowadays fill our classrooms want to learn in a different way.

In response to this demand, immediacy and spontaneity, as well as collaboration and reuse of materials, have become features of the new forms of teaching (García-Valcárcel, 2016). Our students are accustomed to audiovisual stimuli and the versatility of information communication, especially the immediacy when accessing it, so they find traditional educational resources little motivating (Ortiz, 2006: 37-38). This new generation, avid of technology, demands not only a change in the contents and in the way they are presented, 
but also instant solutions to their needs and an updated access to information, beyond the timetables and physical spaces of the Centers. Along these lines, several recent studies confirm not only the positive orientation of current students towards technology, audiovisual media and the use of mobile devices, but also the absolute majority in the demand for on-line activities in their educational development (Dahlstrom, 2015).

The integration of ICTs in this new society, infoxicated by the excess of information, determines the success or failure of students by their ability to select the most relevant sources, so universities will have to prepare future teachers dedicated to the production and development of ICT-based systems, which will serve to generate new knowledge, because, as Cantón (2000: 451) states, "What will add value to a person is their ability to introduce an improvement in the product or service, their ability to learn from the innovations of others, and their ability to adapt to unpredictable situations". Against this backdrop, it is necessary to search for new learning scenarios and new content distribution mechanisms. Considering the digital competencies of students as a vector of impact in the design of digital experience is a key element to avoid a gap that may not be initially perceived (Gisbert \& Esteve, 2011: 49).

This new educational approach also requires a change in the role of the teacher, who becomes a curator or content manager, creating, but, above all, selecting and organizing all types of online material (Mena, 2014: 3). Since the curricular integration of ICTs is a pedagogical and not only a technical issue, the availability of materials and teacher training are decisive conditions to make their integration possible. However, the development of educational materials is a complex process that involves, on the one hand, the design of computer materials and, on the other, the development of educational materials. As O'Farrill and Tunis (2008: 61) observe, "on the one hand we will have to use and develop the set of techniques and resources inherent to computer science (navigation resources, internal and external links, icons, scripts, multimedia, etc.); and on the other hand we incorporate the elements or dimensions inherent to any material intended for teaching and learning: objectives, activities, contents, etc." These didactic materials are managed by teachers according to their competences, for which their training and updating is a matter of great relevance (Livingstone, 2012: 18).

The design of teaching materials for educational purposes requires that they are developed or selected to be used in an educational activity mediated by ICTs, having to comply with the criteria derived from didactics, such as interactivity, motivation, creativity, collaboration and knowledge representation (GarcíaValcárcel, 2016). In this sense, authoring tools can be considered a new type of software whose objective is to facilitate the creation, publication and management of educational materials in digital format. These tools have generated very important educational products, both for their design and their didactic possibilities, reducing, in addition, the effort required by teachers to produce software, guiding them and offering them predefined elements. (Murray et alii, 2003: 341 et seq.).

The main difference with respect to more traditional educational materials lies in the use of digital tools that favor autonomous use by students and interaction, a fundamental characteristic of the new media; they also usually involve a gamification component, making them highly motivating; and, finally, they also act as evaluation tools.

Their implementation in the curriculum proposes to break the spatio-temporal barriers that dominate traditional teaching by offering open access materials in a more flexible environment (Sevillano, 2015). In this sense, digital teaching materials (DTM) are always reusable, but, in addition, they must be open access so that other teachers can adapt them to their needs. When using them in daily practice, we notice that they offer greater flexibility than traditional printed materials insofar as they are more susceptible to being modified and reused in order to adapt them to the specific needs of a particular classroom or to our interests as teachers.

Contextualization is another important element to consider. The DTMs should not only contain digital resources, but the ways in which they are contextualized for a specific educational use should be considered, contemplating their function and adaptability in larger units, since, as pointed out by M. Area Moreira, "all digital didactic material must be at the service of the pedagogical approach of the course or program in which it will be used and must be used as a means or resource for the achievement of educational objectives" (Area, 2003: 36). 
Finally, the creation of DTMs entails a series of advantages, among which we highlight the promotion of active learning, since the student becomes involved by recognizing the personal benefits and the usefulness of their learning, becoming responsible for the construction of their knowledge and the choice of the most suitable means for it. In this sense, the use of active methodologies allows the acquisition of digital skills through group work, improving the learning process and student performance, because, as Rodriguez \& Espinoza (2017) point out, "a work done in a group in a collaborative way has a more enriching result than the sum of individual work".

\section{DEVELOPMENT}

\section{Objectives}

The main objective of our proposal is the creation of Digital Teaching Materials (DTMs) from computer applications of easy access and design, highlighting the importance of authoring tools for the development of the teaching and learning process. The aim is to facilitate meaningful and autonomous learning, as well as the acquisition of digital competences of the students of the subject "Teaching innovation and educational research in the teaching of language and literature (Spanish, Latin and Greek)" of the Master in Teacher Training of Mandatory Middle School and High School, Vocational Training and Language Teaching (Interuniversity) by the Universidad de La Laguna, with the ultimate goal of being able to carry out the creation and development of their own DTMs related to the field of Humanities.

Specific objectives include:

$>$ Training in planning, design and elaboration of DTMs.

$>$ To know and evaluate the feasibility of the main tools and applications (Apps) available for the elaboration of DTMs.

$>$ Training in the use of innovation techniques to transform teaching guides with the inclusion of DTMs.

$>$ Training in the control of the use of Digital Teaching Materials in the classroom.

\section{Methodology}

For the development of the project, therefore, the creation of proprietary didactic materials, known as authoring tools, and the presentation of the main free tools for the creation of contents are promoted in order to assess their effectiveness and pedagogical feasibility. For this new type of software, different free programs or web applications are suggested, to be chosen by the students according to their needs and their level of skills and knowledge. At this point, the tutor's role as facilitator is of vital importance, since they can guide the students among the multiple possibilities available online, enabling them to optimize resources and encouraging their critical thinking about the functionality of the tools used.

In order to achieve the proposed objectives, we have sought to promote self-directed learning in which students work in teams in virtual environments. The project-based learning methodology involves, in this case, promoting or encouraging the selection of applications or tools according to the needs of each teacher or, as is the case, of the future teacher for the development of their DTM. This generates an autonomy that will help the teacher to solve any situation regardless of the material or virtual resources available online.

We then propose the creation of different materials to form a collection or sequence of activities hosted on a digital platform that allows the creation, management and storage of different types of materials, as well as the sharing of content for later viewing. This type of platform is ideal for collaborative work and information exchange. On the other hand, given that the collections formed by different interactive activities and their possible combinations could be considered as pieces of a puzzle destined to fit perfectly with each other, the choice of activities should respond to a didactic criterion or "educational relevance" (Rodríguez, 2005); that is, choosing resources that can fulfill a similar function and combining them in a coherent manner to achieve the intended objectives.

Finally, the results are shared online through educational communities, allowing a critical assessment of the work carried out by the other groups. Communication networks, and the commitment to collaborate 
through them, make possible the birth of new projects to share audiovisual resources, adding interactivity and allowing their exhibition on the Internet.

\section{Project}

The experience -as we have pointed out- has been carried out in the subject "Teaching innovation and educational research in the teaching of language and literature (Spanish, Latin and Greek)", a four-monthly subject corresponding to the Master in Teacher Training of Mandatory Middle School and High School Education, Vocational Training and Language Teaching (Interuniversity) by the Universidad de La Laguna, during the academic year 2017-2018. For its development we have a total of 24 students, of whom, according to an initial survey, all have a high liking for computers and $80 \%$ claim to have computer skills. In response to the question "Choose among the competences of the subject the one you consider most important for the future development of your teaching practice", 60\% selected "To know and apply methodologies and basic techniques of educational research and evaluation and to be able to design and develop research, innovation and evaluation projects", and 100\% said they were willing to introduce ICTs in their classes.

With such a favorable scenario for the objectives of the project, we proceeded to choose the most appropriate platform for its development, and Educaplay (https://es.educaplay.com/) was chosen, which made it possible to create, host and publish different multimedia materials, classified by categories according to the age and level of studies of potential users and identified by tags according to the subject matter. These materials are open access and free of charge, and can not only be used from the computer or any mobile device, but also exported to blogs or web pages.

Collaborative environments such as Educaplay are storage tools, similar to any other open access repository, and are, at the same time, communication tools, since they are a powerful means of disseminating materials. To meet the needs of real-time communication, the chat of the virtual classroom of the course and the Google+ community created for the occasion were used.

The dynamics used in the classroom consisted of dividing the students into groups of four for the creation of DTMs and the subsequent formation of collections of activities in an organized, pedagogical and visually attractive way. The main focus was on the organization of the activities by themes and in significant levels from an educational point of view, distinguishing a sequential order when they responded to a progressive difficulty or free when we wanted to promote autonomous learning, in which the students can choose the contents and resources that most interest them and in the order they consider most convenient.

The tools used for the creation of materials were video quiz, word roulette, quizzes, crossword puzzles, interactive maps, word search puzzles and presentations. The choice of these tools was optional for the students, except for the video quiz, which, due to its didactic potential, all groups were advised to include. This exception is based on the advantages it offers as an interactive video, by allowing the association of contents of diverse nature along its narrative line (García-Valcárcel, 2008; García Matamoros, 2014). Videoquiz or hypervideos are characterized both by their ability to expand the information of the sequence of the video sequence, and by their adaptability to the pace of each student and their motivational effectiveness, since they not only transmit exhaustive information on a topic, but also open up questions, raise problems, generate participatory dynamics and increase the attention of students (I Prats, 2003: 62 and 67; Romero, 1996: 130-132).

Finally, the assessment of the activity includes self-evaluation forms, which allow students to be aware of their progress, a satisfaction survey on the results obtained and a final evaluation where the level of content and relevance of the information, the level of creativity and the coherence in the sequence of activities are assessed. The quality of the authoring tools is judged both from a technical and pedagogical point of view, taking into account their design, compatibility, reusability and suitability for the development of the school curriculum. The sum of these data will provide us with an objective assessment of their didactic potential and, consequently, of their curricular integration. 


\section{Results}

As for the results of this experience, we have been able to verify that the skill and knowledge level required by the author of the didactic materials is minimal. The complexity of the production process can be reduced by means of appropriate tools that are easy to use, preferably online (they do not require the installation of any program on our computer), free of charge and assisted by the trainer, who, in this case, acts as a guide for the whole training process. There are increasingly user-friendly tools, but it is up to the teacher to enable students to select the right applications to create their own DTM.

The flexibility of these materials extends to their use by the students themselves, since they can reconfigure them, modifying or expanding them, in another context, thus complying with one of the main characteristics of DTMs, their reusability. In this sense, most of them recognized the usefulness of these tools and showed at the end of the process to have acquired sufficient capacity to create their own materials, a fundamental part in the management and organization of their classes when entering the professional work market.

On the other hand, through collaborative work, students developed their ability to acquire knowledge and solve problems by working in groups, becoming aware that learning is a lifelong process. In addition to the essentially social nature of this type of learning, there is the experience of making educational videos for use in the classroom with well-defined pedagogical objectives, a creative learning process that allows the students' ideas on how to teach certain contents to be put into practice.

We can assert that the effectiveness of an educational innovation experience is related to the way in which its application is carried out in the classroom context and to the presence of significant elements that indicate a direct relationship between its contents, the subject syllabus and those who teach it. In this respect, the results show that the role of teachers in virtual environments is very important to generate a new learning culture and teaching practice.

Finally, there are signs of improvement in learning outcomes and student motivation due, undoubtedly, to a more interactive type of teaching and more meaningful learning, as ICTs helped to design didactic activities that contributed to involve students, who showed a great predisposition to participate in collaborative activities, generating an environment of communication among their peers, and to disseminate their results in social networks. We have confirmed once again how social interaction favors learning.

\section{CONCLUSIONS}

The implementation of the development of DTMs in the teaching-learning process seeks, above all, that future teachers are able to generate their own materials based on specific pedagogical models and are able to face new situations and new learning scenarios in order to successfully solve their future teaching practice.

The success of the project-based learning and collaborative work carried out in the classroom has fostered a critical and enriching environment and has provided students with the necessary tools to be able to innovate in any subject they will teach in the future, once the technological gap they face has been overcome. The results derived from the satisfaction survey reveal that a high degree of success has been achieved with respect to the initial objectives.

Therefore, the creation of DTMs facilitates the development in students of various skills related to autonomous and meaningful learning, working collaboratively, using various technological resources and sharing the results obtained online, an environment that is very close to their reality outside the classroom.

The conclusions we reached regarding the tools used are, on the one hand, that digital video expands the traditional functions of video in teaching by allowing greater interactivity and, as a result, is revitalizing the use of audiovisual communication from an educational perspective; on the other hand, virtual communities and open access educational platforms enable the publication of materials to be shared, while fostering new communication channels within the culture of social networks. In this context, the DTMs

driven by social networks allow for the reconstruction and generation of new content through collaborative tools. 
The great complexity of training our students in digital competence is that of seeking answers for a world that is still unknown to us. Zygmunt Bauman (2015) was right when he stated that our society was a sort of liquid modernity, insofar as the values and aspirations of humanity are transforming at a dizzying pace. Therefore, Universities will have to prepare professionals capable of elaborating and designing new didactic materials that fit their needs and the new times. It arises, therefore, the need for the inclusion of digital competences in the development of the subjects of the Master in Teacher Training of Mandatory Middle School and High School Education, Vocational Training and Language Teaching (Interuniversity) by the Universidad de La Laguna, and its application in the curricular teaching practices carried out in Middle School and High School Centers.

The Master's students, aged between 24 and 30 years, belong to the millennial generation, using the terminology coined by Howe \& Strauss (2000). They were not born with technology under their arms, but they do handle any mobile device or computer device without any difficulty, interacting with them almost intuitively. These young people, who are very interested in any technological novelty, will undoubtedly know how to transmit their knowledge and enthusiasm to the new generations.

\section{ACKNOWLEDGEMENT}

Translated \& edited by American Publishing Services (https://americanpublishingservices.com/).

\section{REFERENCES}

Area Moreira, M. (2003). De los webs educativos al material didáctico web (From educational websites to didactic web material). Revista Comunicación y Pedagogía, (188), 32-38.

Bauman, Z. (2015). Modernidad líquida (Liquid modernity). Fondo de cultura económica.

Cantón, I. (2000). Las tecnologías como utopía en la sociedad de la información y el conocimiento y su incidencia en las instituciones educativas (Technologies as utopia in the information and knowledge society and their impact on educational institutions). Las Organizaciones Educativas en la Sociedad Neoliberal, Granada: Grupo Editorial Universitario, pp. 445-461.

Dahlstrom, E. (2015). Educational technology and faculty development in higher education. Educause Center for Analysis and Research. Retrieved from http://net.educause.edu/ir/library/pdf/ers1507.pdf

García Matamoros, M.A. (2014). Uso instruccional del video didáctico (Instructional use of didactic video). Revista de Investigación, 38(81), 43-68.

García-Valcárcel Muñoz-Repiso, A. (2008). El hipervídeo y su potencialidad pedagógica (Hypervideo and its pedagogical potential). Revista Latinoamericana de Tecnología EducativaRELATEC, 7(2), 69-79.

García-Valcárcel Muñoz-Repiso, A. (2016). Recursos digitales para la mejora de la enseñanza y el aprendizaje (Digital resources for the improvement of teaching and learning). Retrieved from https:/gredos.usal.es/jspui/bitstream/10366/131421/1/Recursos\%20digitales.pdf

Gisbert, M., \& Esteve, F. (2011). Digital Learners: la competencia digital de los estudiantes universitarios (Digital Learners: the digital competence of university students). La Cuestión Universitaria, 6(7), $48-59$.

Howe, N., \& Strauss, W. (2000). Millennials Rising: The Next Great Generation. Vintage.

i Prats, J.F. (2003). Educación en medios y competencia emocional (Media education and emotional competence). Revista Iberoamericana de Educación, 32(1), 49-69.

Livingstone, S. (2012). Critical reflections on the benefits of ICT in education. Oxford Review of Education, 38(1), 9-24.

Mena Muñoz, S. (2014). Herramientas contra la infoxicación en los Social Media: Los "Content Curators" (Tools against infoxication in Social Media: The "Content Curators"). Ámbitos. Revista Internacional de Comunicación, (24), 1-12. 
Murray, T., Blessing, S., \& Ainsworth, S. (Eds.). (2003). Herramientas de creación para entornos de aprendizaje de tecnología avanzada: Hacia un software educativo adaptativo, interactivo e inteligente rentable (Authoring tools for advanced technology learning environments: Towards cost-effective adaptive, interactive, intelligent educational software). Springer Science \& Business Media.

O'Farrill, J.L.M., \& Tunis, E.H. (2008). Las herramientas de autor en el proceso de producción de cursos en formato digital (Authoring tools in the digital course production process). Pixel-Bit. Revista de Medios y Educación, (33), 59-72.

Ortiz Colón, A. (2006). La implantación de las TIC o el uso de internet en la escuela (The implementation of ICTs or the use of the Internet at school). Innovación educativa, (16), 31-45.

Rodríguez Illera, J.L., Escofet, A., \& Azzato, M. (2005). Un sistema abierto para la creación de contenidos educativos digitales (An open system for the creation of digital educational content). RED. Revista de Educación a Distancia, (IV). Retrieved from http://www.um.es/ead/red/M4/

Rodríguez Zamora, R., \& Espinoza Núñez, L.A. (2017). Trabajo colaborativo y estrategias de aprendizaje en entornos virtuales en jóvenes universitarios (Collaborative work and learning strategies in virtual environments in young university students). RIDE. Revista Iberoamericana para la Investigación y el Desarrollo Educativo, 7(14), 86-109.

Romero Tena, R. (1996). Utilización didáctica del vídeo (Didactic use of video). II Jornadas sobre Medios de Comunicación, Recursos y Materiales para la Mejora Educativa (pp. 127-149). Sevilla: Ayuntamiento de Sevilla, Centro Municipal de Investigación y Dinamización Educativa: Universidad de Sevilla, Secretariado de Recursos Audiovisuales y Nuevas Tecnologías.

Sevillano-García, M.L. (2015). El contexto socioeducativo de la ubicuidad y la movilidad (The socioeducational context of ubiquity and mobility). In E. Vázquez-Cano \& M.L. Sevillano García (Eds.), Dispositivos digitales móviles en educación. El aprendizaje ubicuo. Madrid: Narcea. 